\title{
Переваримость питательных веществ, баланс и использование азота, кальция и фосфора при введении в рацион бройлеров триптофана и хондропротекторной кормовой добавки
}

\author{
Саломатин В.В., доктор сельскохозяйственных наук, профессор \\ Ряднов А.А., доктор биологических наук, профессор \\ Злепкина Н.А., кандидат сельскохозяйственных наук, доцент \\ Коноблей Т.В., кандидат сельскохозяйственных наук, доцент \\ ФГБОУ ВО «Волгоградский государственный аграрный университет»
}

\begin{abstract}
Аннотация: Представлены результаты исследований блияния въода 6 состав рациона препарата триптофана и кормовой смеси «Хондро Тан» на переваримость и использование питательных веществ иыплятами-бройлерами (кросс Кобб-500, 50 голов в группе). Установлено, что бъедение 6 состав комбикорма препарата триптофана (400 2/m во бсех опытных группах) и дополнительное скармлибание смеси «Хондро Тан» (I опытная группа - 300 г на $1 \mathrm{~m}$ комбикорма; II опытная - 350 2/m; III опытная - 400 г/m) cnoсобствует повышению переваримости и использования бройлерами питательных веществ корма. Коэфрициент переваримости сухого вещества рациона 6 I, II и III опытных группах был быше, чем у молодняка контрольной группи, соответственно на 0,80 ( $P<0,01)$; 1,95 ( $P<0,001)$ и 1,55\% ( $<<0,01)$, сырого протеина - на 1,03 ( $<<0,01)$; $1,68(P<0,001)$ и 1,27\% (P<0,01), сырого жира - на 0,92 $(P<0,05) ; 1,90(P<0,001)$ и 1,59\% $(P<0,01)$, сырой клетчатки - на 0,75 (P<0,05); 1,65 (P<0,001) и 1,33\% (P<0,01). В теле молодняка I, II и III опытных групп азота отложилось больше, чем 6 контрольной группе, соответственно на 0,13 (3,88\%; $P<0,05) ; 0,28$ (8,36\%; $P<0,001)$ и 0,20 г (5,97\%; $P<0,01)$. Коэффициент использования азота от принятого с кормом был быше у бройлеров опытных групп, б сравнении с контрольной группой, соответственно на 2,00; 3,82 (P<0,01) и 2,68\% (P<0,01), кальция - на 1,04; 4,09 (P<0,05) и 3,74\% (P<0,05), фосфора - на 4,64; 8,09 (P<0,01) и 6,23\% (P<0,05). Улучиение переваримости рациона 6 опытных группах сопровождалось повышением ряда биохимических показателей крови, характеризующих белковый и минеральный обмен. Пребосходство по перебаримости и использованию питательных веществ рациона установлено бо II опытной группе.
\end{abstract}

Ключебые слова: иьллята-бройлеры; триптофан; кормовая смесь "Хондро Тан»; коэффрициент перебаримости; сухое вещество корма; сырой протеин; сырой жир; баланс и использование азота, кальция и фросфора; биохимические показатели крови.

Введение. Хорошо известно [1], что полностью реализовать генетический потенциал продуктивности птицы можно только при кормлении ее комбикормами, сбалансированными по всем питательным и биологически активным веществам в соответствии с физиологическими потребностями. Проблема полноценного протеинового питания, по существу, является проблемой обеспеченности аминокислотами, поскольку кормовые белки, как таковые, перестают существовать уже на стадии пищеварения. Во всех дальнейших биохимических процессах участвуют продукты их ферментативного расщепления, в основном, аминокислоты.

Интенсификация птицеводства напрямую связана с полноценными кормами, содержащими необходимое количество питательных веществ, особенно протеина и лимитирующих аминокислот. При недостатке в рационе той или иной незаменимой аминокислоты потребность в протеине возрастает. Поэтому в практике птицеводства необходимо использовать синтетические препараты аминокислот.

На переваримость и использование питательных веществ корма оказывают влияние множество факторов, среди которых большое значение имеют минеральные вещества [3].

Для повышения усвоения минеральных веществ в организме птицы необходимо использовать 
препараты, обладающие хондропротекторными свойствами.

Сообщалось, что при недостатке триптофана в организме замедляется рост молодняка, и, как следствие, повышаются затраты кормов на производство продукции [6]. Дефицит этой аминокислоты возникает в связи с разным ее усвоением из различных кормов. В случае использования мясокостной муки, подсолнечного шрота, зернобобовых и других кормов при норме триптофана в рационе может возникнуть его нехватка в организме птицы из-за низкой усвояемости. Дефицит этой аминокислоты также может возникнуть при использовании комбикормов с высоким содержанием кукурузы. Введение в полнорационные комбикорма цыплят-бройлеров опытных групп препаратов триптофана в дозе $10 \%$ от количества этой аминокислоты в основном рационе оказало положительное влияние на зоотехнические показатели молодняка. Применяли препараты с содержанием аминокислоты 98 и 5\%. Добавка препаратов триптофана в рацион обеспечивала за 7 недель выращивания бройлеров повышение среднесуточного прироста живой массы, в сравнении с контролем, соответственно на 3,4 и 1,9\%, при снижении затрат корма на 1 кг прироста на 4,5 и 2,7\%.

\begin{tabular}{|c|c|c|c|}
\hline Группа & $\begin{array}{c}\text { Количество } \\
\text { цыплят- } \\
\text { бройлеров, } \\
\text { голов }\end{array}$ & $\begin{array}{c}\text { Продол- } \\
\text { жительность } \\
\text { выращи- } \\
\text { вания, дней }\end{array}$ & $\begin{array}{c}\text { Особенности кормления цыплят- } \\
\text { бройлеров }\end{array}$ \\
\hline Контрольная & 50 & 40 & Полнорационный комбикорм (ПК) \\
\hline І опытная & 50 & 40 & $\begin{array}{l}\text { ПК с } 0,04 \% \text { препарата триптофана }+300 \\
\text { г/т кормовой смеси «Хондро Тан» }\end{array}$ \\
\hline II опытная & 50 & 40 & $\begin{array}{l}\text { ПК с } 0,04 \% \text { препарата триптофана }+350 \\
\text { г/т кормовой смеси «Хондро Тан» }\end{array}$ \\
\hline III опытная & 50 & 40 & $\begin{array}{l}\text { ПК с 0,04\% препарата триптофана }+400 \\
\text { г/т кормовой смеси «Хондро Тан» }\end{array}$ \\
\hline
\end{tabular}

Триптофан - одна из незаменимых аминокислот, исходный продукт для синтеза в организме белков, никотиновой кислоты, предшественник ряда других физиологически активных веществ [7].

Учитывая вышеизложенное, нами в предыдущем опыте изучались разные дозы ввода в состав полнорационного комбикорма препарата триптофана; было установлено, что в условиях «Птицефабрики Краснодонская», с учетом состава и питательности комбикорма, оптимальным уровнем ввода препарата этой аминокислоты является 400 г на 1 т корма.

В связи с этим, изучение влияния ввода в рацион триптофана совместно с кормовой смесью «Хондро Тан» на переваримость и использование питательных веществ рациона цыплятами-бройлерами является актуальным.

Материал и методика исследований. Для проведения опыта по методу аналогов были сфор- мированы четыре группы цыплятбройлеров кросса «Кобб-500» суточного возраста (контрольная и три опытные) по 50 голов в каждой. Срок выращивания молодняка составил 40 дней. Опыт проводили по схеме, представленной в табл. 1.

В кормлении цыплят были использованы полнорационные комбикорма ПК-0 (с 1 по 4 день жизни); ПК-2 (с 5 по 14 день); ПК-5 (с 15 по 28 день); ПК-6 (с 29 по 34 день) и ПК-7 (с 35 по 40 день).

Изготовленные комбикорма по набору ингредиентов отличались тем, что в опытные партии вводили препарат триптофана согласно схеме опыта. Также молодняку опытных групп дополнительно добавляли кормовую смесь «Хондро Тан».

Подопытные цыплята-бройлеры при напольном содержании размещались на глубокой подстилке в специально отгороженных секциях. Фронт кормления

\begin{tabular}{|c|c|c|c|c|}
\hline \multirow{2}{*}{ Показатель } & \multicolumn{4}{|c|}{ Грyпna } \\
\hline & контрольная & І опытная & II опытная & III опытная \\
\hline \multicolumn{5}{|c|}{ Коэффициенты переваримости питательных веществ рациона, \% } \\
\hline Сухое вещество & $76,03 \pm 0,15$ & $76,83 \pm 0,20$ & $77,98 \pm 0,15$ & $77,58 \pm 0,32$ \\
\hline Сырой протеин & $91,30 \pm 0,20$ & $92,33 \pm 0,20$ & $92,98 \pm 0,29$ & $92,57 \pm 0,20$ \\
\hline Сырой жир & $76,73 \pm 0,32$ & $77,65 \pm 0,22$ & $78,63 \pm 0,26$ & $78,32 \pm 0,21$ \\
\hline Сырая клетчатка & $16,17 \pm 0,20$ & $16,92 \pm 0,21$ & $17,82 \pm 0,25$ & $17,50 \pm 0,29$ \\
\hline \multicolumn{5}{|c|}{ Баланс и использование азота } \\
\hline Отложено в теле, г & $3,35 \pm 0,02$ & $3,48 \pm 0,04$ & $3,63 \pm 0,05$ & $3,55 \pm 0,04$ \\
\hline $\begin{array}{c}\text { Коэффициент } \\
\text { использования, } \\
\text { \% от принятого }\end{array}$ & $56,68 \pm 0,57$ & $58,68 \pm 0,87$ & $60,50 \pm 1,02$ & $59,36 \pm 0,61$ \\
\hline \multicolumn{5}{|c|}{ Баланс и использование кальция } \\
\hline Отложено в теле, г & $0,67 \pm 0,02$ & $0,69 \pm 0,01$ & $0,75 \pm 0,02$ & $0,73 \pm 0,01$ \\
\hline $\begin{array}{c}\text { Коэффициент } \\
\text { использования, } \\
\text { \% от принятого }\end{array}$ & $45,58 \pm 1,01$ & $46,62 \pm 0,70$ & $49,67 \pm 1,13$ & $49,32 \pm 0,75$ \\
\hline \multicolumn{5}{|c|}{ Баланс и использование фосфора } \\
\hline Отложено в теле, г & $0,49 \pm 0,02$ & $0,56 \pm 0,02$ & $0,62 \pm 0,02$ & $0,59 \pm 0,02$ \\
\hline $\begin{array}{c}\text { Коэффиициент } \\
\text { использования, } \\
\% \text { от принятого }\end{array}$ & $36,84 \pm 1,66$ & $41,48 \pm 1,65$ & $44,93 \pm 1,28$ & $43,07 \pm 1,38$ \\
\hline
\end{tabular}


и поения, плотность посадки, параметры микроклимата и режим освещения во всех группах были одинаковыми.

Для определения переваримости и использования питательных веществ рациона был проведен физиологический опыт на 6 цыплятах-бройлерах из каждой группы. У данных особей был также проведен биохимический анализ крови.

Полученные в опыте цифровые данные были статистически обработаны с определением уровня достоверности различий между группами по t-критерию Стьюдента.

Результаты исследований и их обсуждение. Ранее указывалось [2], что при изучении эффективности использования в кормлении птицы новых кормов, кормовых добавок и биологически активных препаратов особое внимание уделяется переваримости и использованию питательных веществ рациона, так как от данных процессов во многом зависит ее продуктивность. Данные по переваримости и использованию бройлерами питательных веществ рациона представлены в табл. 2.

Коэффициент переваримости сухого вещества у цыплят-бройлеров I, II и III опытных групп был выше, по сравнению с молодняком птицы контрольной группы, соответственно на $0,80(\mathrm{P}<0,01) ; 1,95$ $(\mathrm{P}<0,001)$ и 1,55\% ( $<<0,01)$; сырого протеина - на 1,03 (P<0,01); 1,68 $(P<0,001)$ и 1,27\% (P<0,01); сырого жира - на 0,92 ( $<<0,05) ; 1,90$ $(\mathrm{P}<0,001)$ и 1,59\% $(\mathrm{P}<0,01)$; сырой клетчатки - на 0,75 ( $<<0,05) ; 1,65$ $(\mathrm{P}<0,001)$ и $1,33 \%(\mathrm{P}<0,01)$.

При этом у цыплят-бройлеров II опытной группы коэффициент переваримости сухого вещества был выше, чем в I и III опытных группах, соответственно на 1,15 $(\mathrm{P}<0,001)$ и $0,40 \%$, сырого протеина - на 0,65 и 0,41\%, сырого жира - на $0,98(\mathrm{P}<0,05)$ и $0,31 \%$, сы- рой клетчатки - на $0,90(\mathrm{P}<0,05)$ и $0,32 \%$.

Изучение баланса и использования азота, кальция и фосфора рациона бройлерами имеет большое значение, так как они характеризуют уровень использования питательных веществ организмом и интенсивность обменных процессов.

Установлено, что баланс азота во всех группах был положительным. Однако в теле цыплят-бройлеров I, II и III опытных групп азота отложилось больше, чем в контрольной группе, соответственно на 0,13 (3,88\%; $\mathrm{P}<0,05) ; 0,28$ $(8,36 \% ; \mathrm{P}<0,001)$ и 0,20 г $(5,97 \%$; $\mathrm{P}<0,01)$. Коэффициент использования азота от принятого его количества с кормом у бройлеров I, II и III опытных групп был выше, в сравнении с молодняком контрольной группы, соответственно на 2,0; 3,82 ( $<<0,01)$ и $2,68 \%(\mathrm{P}<0,01)$.

Между бройлерами опытных групп превосходство по использованию азота рациона выявлено у II группы, где азота в теле было отложено больше, по сравнению с I и III группами, соответственно на 0,15 (4,31\%; Р<0,05) и 0,08 г (2,25\%); коэффициент использования азота от принятого его количества с кормом также был выше у бройлеров II опытной группы, в сравнении с молодняком I и III опытных групп, соответственно на 1,82 и $1,14 \%$.

Известно, что для обеспечения высокой продуктивности сельскохозяйственной птицы необходимы полнорационные комбикорма, сбалансированные по энергии, протеину и минеральным веществам [4]. Наиболее важными минеральными макроэлементами являются фосфор и кальций. При этом сельскохозяйственная птица отличается высокой напряженностью кальциевофосфорного обмена.

Фосфор содержится во всех тканях животного организма и является непременным компонентом его внутренней среды. Все виды обмена в организме неразрывно связаны с превращением фосфорной кислоты. Фосфор входит в структуру нуклеиновых кислот, благодаря фосфорилированию осуществляется кишечная адсорбция, гликолиз, прямое окисление углеводов, транспорт липидов, обмен аминокислот и т.д. До 80-85\% фосфрора организма содержится в скелете. Кальциевые соли обеспечивают нормальную работу сердца и других органов. Кальций активизирует ферменты протромбокиназу, липазу поджелудочной железы, фосфатазу слюны, энтерокиназу, лецитиназу, актомиозинаденозинтрифосфатазу, стабилизирует трипсин. Ионы кальция обеспечивают синтез молочной кислоты [5].

Учитывая важную биологическую роль кальция и фосфора в организме, нами был изучен их обмен у подопытных цыплятбройлеров.

В теле цыплят I, II и III опытных групп было отложено больше кальция, чем в контрольной группе, соответственно на 0,02 (2,83\%); 0,08 (11,94\%; $\mathrm{P}<0,05)$ и $0,06$ г (8,95\%; $\mathrm{P}<0,05)$. Коэффициент использования кальция от принятого с рационом в I, II и III опытных группах, по сравнению с молодняком контрольной группы, увеличился соответственно на 1,$04 ; 4,09(\mathrm{P}<0,05)$ и $3,74 \%$ $(\mathrm{P}<0,05)$.

Отложение фосфора в теле цыплят-бройлеров I, II и III опытных групп, по сравнению с молодняком контрольной группы, было больше соответственно на 0,07 (14,29\%; $\mathrm{P}<0,05) ; 0,13$ (26,53\%; $\mathrm{P}<0,01)$ и 0,10 г $(20,41 \%$; $\mathrm{P}<0,01)$. Коэффициент использования фосфора от принятого с кормом у цыплят-бройлеров I, II и III опытных групп, в сравнении с бройлерами контрольной группы, увеличился соответствен- 
но на 4,$64 ; 8,09(\mathrm{P}<0,01)$ и $6,23 \%$ $(P<0,05)$.

Результаты фризиологического опыта согласуются с данными биохимических исследований крови. Так, содержание общего белка в сыворотке крови бройлеров I, II и III опытных групп, в сравнении с контрольной группой, было больше соответственно на 0,82 (1,92\%; $\mathrm{P}<0,05) ; 1,45 \quad(3,40 \% ; \mathrm{P}<0,01)$ и $1,22$ г/л (2,86\%; $\mathrm{P}<0,01)$, альбуминов - на 0,35 (2,08\%; $\mathrm{P}<0,05)$; $0,74$ (4,40\%; $\mathrm{P}<0,001)$ и 0,57 г/л (3,39\%; $\mathrm{P}<0,01)$, глобулинов - на 0,47 (1,82\%); 0,71 (2,75\%; $\mathrm{P}<0,05)$ и 0,65 г/л (2,52\%), общего кальция - на 0,09 (3,09\%); 0, 16 (5,50\%; $\mathrm{P}<0,001)$ и 0,12 ммоль/л $(4,12 \%$; $\mathrm{P}<0,05)$, неорганического фосфора - на 0,07 (3,63\%); 0,13 (6,73\%; $\mathrm{P}<0,001)$ и 0,09 ммоль/л $(4,66 \%$; $\mathrm{P}<0,05)$.

Заключение. Результаты исследований свидетельствуют о том, что использование в кормлении цыплят-бройлеров дополнительного ввведения триптофрана (0,04\%) и кормовой смеси «Хон- дро Тан» (300-400 г/т) способствует повышению переваримости питательных веществ корма и лучшему использованию азота, кальция и фосфора. Лучше показатели отмечены в группе, получавшей «Хондро Тан» в дозе 350 г/т.

\section{Литература}

1. Байковская, Е.Ю. Синтетический глицин в комбикормах для цыплят-бройлеров / Е.Ю. Байковская, Е.М. Абашкина, В.А. Манукян // Птицеводство. - 2021. №3. - С. 13-16.

2. Влияние биологически активных препаратов на переваримость и использование питательных веществ рациона цыплятами-бройлерами / В.В. Саломатин, А.Т. Варакин, Т.В. Коноблей, Е.Б. Радзиевский // Птицеводство. - 2021 . - №2. - С. 16-20.

3. Переваримость и использование питательных веществ корма хряками-производителями при введении в рационы минеральных добавок / В.В. Саломатин, А.Т. Варакин, Р.Н. Муртазаева, В.А. Корнилова // Кормление с.-х. животных и кормопроизводство. - 2019. - №2. - С. 3-10.
4. Фосфаты в комбикормах для птицы селекции СгЦ «Смена» / И.А. Егоров, В.Г. Вертипрахов, Т.Н. Ленкова [и др.]. // Птицеводство. - 2018. №1 0. - С. 14-19.

5. Манукян, В.А. Влияние баланса электролитов в рационе на некоторые показатели минерального обмена у кур-несушек / В.А. Манукян, Е.Ю. Байковская, А.В. Силаева // Птицеводство. - 2020. - №10. - С. 35-39.

6. Харламов, К.В. Влияние триптофана на продуктивные качества цыплятбройлеров // Достижения науки и техники АПК. - 2010. - №8. - С. 51-52. 7. Злепкин, В.А. Эффективность использования биологически активных добавок при выращивании цыплятбройлеров на промышленной основе / В.А. Злепкин, В.В. Саломатин, Д.А. Злепкин. - Волгоград: ВолГАУ, 2019. - 124 с.

\section{Для контакта с авторами:}

Саломатин Виктор Васильевич

Ряднов Алексей Анатольевич Злепкина

Наталья Александровна

Коноблей Татьяна Викторовна

Тел.: 8 (8442) 41-77-13

\title{
Digestibility of Dietary Nutrients, Retention of Nitrogen, Calcium, and Phosphorus in Broilers Fed Diets Supplemented with Tryptophan and a Chondroprotective Feed Additive
}

\author{
Salomatin V.V., Ryadnov A.A., Zlepkina N.A., Konobley T.V. \\ Volgograd State Agrarian University
}

\begin{abstract}
Summary: The effects of additional supplementation of diets for broilers (cross Cobb-500, 1-40 days of age, 50 birds per treatment) with tryptophan (400 ppm) and chondroprotective feed additive "Chondro Tan" ("above" the basic diets, 300; 350 and 400 ppm respective to treatments I, II, and III) on the digestibility and retention of dietary nutrients and biochemical blood indices were studied. It was found that digestibility coefficient for dietary dry matter in treatments I, II, and III was higher in compare to control treatment (fed non-supplemented diets) by $0.80(P<0.01) ; 1.95(P<0.001)$ and $1.55 \%(P<0.01)$, respectively; for crude protein higher by $1.03(P<0.01) ; 1.68$ $(P<0.001)$ and $1.27 \%(P<0.01)$; for crude fat by $0.92(P<0.05) ; 1.90(P<0.001)$ and $1.59 \%(P<0.01)$; for crude fiber by $0.75(P<0.05) ; 1.65(P<0.001)$ and $1.33 \%(P<0.01)$. The deposition of nitrogen in the body was higher by 0.13 (3.88\%; $P<0.05) ; 0.28$ (8.36\%; $P<0.001)$ and $0.20 \mathrm{~g} /$ bird (5.97\%; $P<0.01)$. The retention coefficients were higher by 2.00; $3.82(P<0.01)$ and $2.68 \%(P<0.01)$ for nitrogen; by 1.04; $4.09(P<0.05)$ and $3.74 \%(P<0.05)$ for calcium; by $4.64 ; 8.09(P<0.01)$ and $6.23 \%(P<0.05)$ for phosphorus. These improvements in the digestibility and retention of dietary nutrients were accompanied by the significant increases in the content of total protein and protein fractions, calcium, and phosphorus in blood serum. The best parameters of feed efficiency was found in treatment II.
\end{abstract}

Keywords: broiler chicks; tryptophan; bioactive feed additive "Chondro Tan"; digestibility coefficient; dietary dry matter; crude protein; crude fat; digestibility and retention of dietary nitrogen, calcium, and phosphorus; biochemical blood indices. 